\title{
Deteksi Simultan Kuersetin dan Rutin Menggunakan Screen-Printed Carbon Electrode Termodifikasi Grafena
}

\section{Simultaneous Detection of Quercetin and Rutin at Graphene Modified Screen Printed Carbon Electrode}

\author{
Tamia Elinda $^{1}$, Wulan Tri Wahyuni ${ }^{1,2^{*}}$, Eti Rohaeti $^{1}$ \\ ${ }^{1}$ Divisi Kimia Analitik Departemen Kimia Fakultas MIPA Institut Pertanian Bogor \\ Gedung Departemen Kimia Level 1, Jalan Tanjung No.3 Kampus IPB Dramaga, Bogor, 16680, Indonesia \\ ${ }^{2}$ Pusat Studi Biofarmaka Tropika LPPM Institut Pertanian Bogor \\ Kampus IPB Taman Kencana No. 3, Bogor, 16128, Indonesia \\ *Corresponding author: wulantriws@apps.ipb.ac.id
}

Receive: April 2019; Revision: April 2019; Accepted: May 2019; Available online: May 2019

\begin{abstract}
Abstrak
Kuersetin dan rutin merupakan senyawa antioksidan alami yang termasuk golongan flavonoid. Senyawa ini dapat dideteksi dengan beberapa teknik analisis, salah satunya dengan teknik elektrokimia. Pada penelitian ini, deteksi simultan kuersetin dan rutin dilakukan dengan teknik voltametri siklik menggunakan screen printed carbon electrode (SPCE) termodifikasi grafena. Elektrode disiapkan melalui modifikasi elektrode kerja SPCE dengan campuran grafena:natrium poliakrilat (1:1). Larutan etanol 70\%:bufer fosfat $\mathrm{pH} 7$ (6:4) digunakan sebagai elektrolit dalam pengukuran kuersetin dan rutin. Hasil penelitian menunjukkan puncak oksidasi kuersetin dan rutin terdeteksi pada potensial $0.179 \mathrm{~V}$ dan $0.310 \mathrm{~V}$ vs Ag/AgCl. SPCE termodifikasi grafena menghasilkan intensitas arus oksidasi dan sensitivitas yang lebih tinggi pada pengukuran kuersetin dan rutin. Deteksi simultan kuersetin dan rutin menggunakan SPCE termodifikasi grafena menunjukkan linearitas dengan $R^{2}=0.9905$ dan $R^{2}=0.9816$, masing-masing untuk kuersetin dan rutin. Limit deteksi pengukuran kuersetin dan rutin masingmasing sebesar $0.5369 \mathrm{mM}$ dan $0.7495 \mathrm{mM}$ serta limit kuantitasi sebesar $1.7898 \mathrm{mM}$ dan $2.4985 \mathrm{mM}$. Presisi pengukuran kuersetin dan rutin memiliki nilai simpangan baku relatif (\%SBR) sebesar $2.14 \%$ dan $2.44 \%$, berturut-turut untuk kuersetin dan rutin. Hal ini menunjukkan bahwa SPCE termodifikasi grafena cukup potensial untuk deteksi simultan kuersetin dan rutin secara elektrokimia.
\end{abstract}

Kata kunci: Grafena, kuersetin, rutin, screen printed carbon electrode, voltametri siklik.

\begin{abstract}
Quercetin and rutin are natural antioxidant from flavonoid group. The compounds can be detected using several analytical technique, including electrochemical technique due to its redox activity. In this study, simultaneous detection of quercetin and rutin was performed at graphene-modified screen printed carbon electrode (SPCE) using cyclic voltammetry technique. Graphene-modified SPCE was prepared from mixture of graphene:sodium polyacrylate (1:1) via drop casting method. Ethanol 70\%:phosphate bufer pH 7 (6:4) was used as electrolyte solution for quercetin and rutin measurement. The result shows that oxidation peak of quercetin and rutin was detected at potential of $0.179 \mathrm{~V}$ and $0.310 \mathrm{~V}$ vs $\mathrm{Ag} / \mathrm{AgCl}$, respectively. Graphene-modified SPCE produce higher intensity of oxidation current and higher sensitivity for quercetin and rutin measurement. Simultaneous detection of quercetin and rutin at graphene modified SPCE provide linearity with $R^{2}=0.9905$ and $R^{2}=0.9816$, respectively for quercetin and rutin. Detection limits of quercetin and rutin respectively was $0.5369 \mathrm{mM}$ and $0.7495 \mathrm{mM}$ while limit quantitation was $1.7898 \mathrm{mM}$ dan $2.4985 \mathrm{mM}$. Precision of quercetin and rutin measurement was moderate with percent relative standard deviation (\%RSD) of $2.14 \%$ and $2.44 \%$, consecutively for quercetin and rutin. This suggests that graphene-modified SPCE is potential for simultaneous electrochemical detection of quercetin and rutin.
\end{abstract}

Keywords: Cyclic voltammetry, graphene, quercetin, rutin, screen printed carbon electrode.

DOI: $10.15408 / j k v . v 5 i 1.11203$ 


\section{PENDAHULUAN}

Kuersetin dengan nama IUPAC 3,3',4',5,7-pentahidroksiflavon merupakan senyawa flavonoid paling dominan pada sayur dan buah. Struktur kuersetin memiliki gugus hidroksil pada cincin aromatik. Kuersetin dilaporkan dapat berfungsi sebagai antikarsinogenik, antiinflamasi, dan antioksidan (Ozgen et al., 2016). Senyawa ini memiliki aktivitas penangkal radikal dengan keberadaan gugus hidroksil (Sun et al., 2008). Sementara itu, rutin memiliki nama IUPAC 3',4',5,7-tetrahidroksiflavon-3 $\beta$-D-rutinosida.

Selain aktivitas antioksidan, rutin dapat berperan sebagai neuroprotektif, kardioprotektif, dan antikarsinogenik (Ganeshpurkar dan Saluja, 2016).

Deteksi kuersetin dan rutin dapat dilakukan menggunakan beberapa metode, diantaranya kromatografi, spektrofotometri, elektroforesis kapiler, dan spektrofluorometri (Yola et al., 2014b). Metode tersebut memiliki selektivitas, namun memerlukan reagen kimia yang beragam, instrumen yang canggih, preparasi sampel yang rumit, dan analis yang terampil. Metode alternatif yang dapat digunakan untuk deteksi kuersetin dan rutin adalah elektrokimia karena senyawa tersebut bersifat elektroaktif. Elektrokimia banyak dikembangkan untuk deteksi kuersetin dan rutin karena waktu analisis yang cepat dan sensitivitas tinggi.

Salah satu teknik elektrokimia yang telah dikembangkan untuk deteksi kuersetin dan rutin ialah voltametri siklik. Piovesan dan Spinelli (2014) melakukan pengukuran kuersetin menggunakan elektrode pasta karbon termodifikasi polimer poli(vinilpirolidon) dengan limit deteksi $0.17 \mu \mathrm{M}$. Sementara Sun et al., (2008) menggunakan elektrode pasta karbon termodifikasi piridinium untuk mendeteksi rutin dan memperoleh limit deteksi sebesar $35.8 \mu$ M. Franzoi et al., (2008) juga melakukan pengukuran rutin menggunakan elektrode pasta karbon termodifikasi poli(vinilpirolidon) dengan limit deteksi 15 $\mu \mathrm{M}$.

Pengukuran kuersetin dan rutin menggunakan elektrode pasta karbon memberikan limit deteksi yang rendah. Namun demikian, elektrode pasta karbon memiliki kestabilan yang kurang baik dan diperlukan keterampilan dalam preparasi elektrode agar diperoleh elektrode dengan keterulangan pengukuran yang tinggi. Sebagai penggantinya, pengukuran kuersetin dan rutin dapat dilakukan dengan menggunakan screen printed carbon electrode (SPCE). SPCE memiliki elektrode kerja, elektrode pembanding, dan elektrode penunjang dalam satu tempat, serta memiliki sensitivitas dan keterulangan pengukuran yang tinggi.

Beberapa upaya dilakukan untuk meningkatkan respon arus elektrode kerja, diantaranya melalui modifikasi dengan zat yang dapat meningkatkan laju transfer elektron. Salah satu zat pemodifikasi yang banyak digunakan ialah grafena karena material ini memiliki konduktivitas listrik, konduktivitas termal, dan kekuatan yang baik. Grafena merupakan satu lapis karbon 2D, dengan struktur heksagonal menyerupai satu lapis grafit. Grafena memiliki sifat kelistrikan, termal, dan mekanik yang baik. Material ini memiliki mobilitas pembawa muatan yang tinggi. Grafena memiliki hibridisasi $\mathrm{sp}^{2}$ dan memiliki ikatan van der Waals (Kelly dan Billups, 2012). Berdasarkan penelitian Sun et al., (2013), elektrode karbon gelas yang dimodifikasi grafena dan polimer tercetak molekul polipirola memiliki limit deteksi 0,048 $\mu \mathrm{M}$ untuk deteksi kuersetin.

Beberapa penelitian tentang deteksi simultan kuersetin dan rutin, seperti yang dilaporkan oleh Lin et al., (2006) menggunakan elektrode multi-wall carbonnanotube (MWCNT) dan Yola dan Atar, (2014a) menggunakan MWCNT termodifikasi nanopartikel emas dan $p$-aminotiofenol. Sementara itu, deteksi simultan kuersetin dan rutin menggunakan SPCE termodifikasi grafena secara voltametri siklik belum pernah dilaporkan. Pada penelitian ini dilakukan modifikasi elektrode kerja SPCE dengan grafena, elektrode yang diperoleh digunakan untuk deteksi simultan kuersetin dan rutin dengan teknik voltametri siklik.

\section{METODE PENELITIAN Alat dan Bahan}

Alat-alat yang digunakan, yaitu alatalat ukur gelas, potensiostat EDAQ (Australia, New South Wales), sonikator AS ONE (Church Hill Road, Newtown), neraca analitik Sartorius (Jerman), mikroskop elektron pemayaran (SEM) (ZEISS EVOMA 10), screen printed carbon electrode (SPCE) Dropsens DRP C110 (Lianera, Austria), oven Memmert UM 40 (Jakarta, Indonesia), konektor elektrode, mikropipet 10 dan $250 \mu \mathrm{L}$, 
mikrotip, dan kompartemen sel berbahan teflon. Bahan-bahan yang digunakan, yaitu grafena; $\mathrm{H}_{2} \mathrm{SO}_{4} 0.5 \mathrm{M}$; larutan elektrolit berupa etanol 70\%:bufer fosfat (PB) 0,1 M pH 7 (6:4), kuersetin \& rutin (Sigma Aldrich, St. Louis, Amerika Serikat), natrium poliakrilat $0.05 \%$; kloroform, metanol p.a, etanol p.a, dan air deionisasi.

\section{Modifikasi SPCE menggunakan Grafena}

Modifikasi SPCE menggunakan grafena dilakukan dengan metode drop casting mengacu pada Jampasa et al., (2016) dengan modifikasi dan Teng et al., (2016) dengan modifikasi. Permukaan SPCE dibilas menggunakan air deionisasi. SPCE diaktivasi menggunakan $\mathrm{H}_{2} \mathrm{SO}_{4} \quad 0.5 \quad \mathrm{M}$ dengan cara dipayar pada jendela potensial -0.2 s.d. $1.3 \mathrm{~V}$ pada kecepatan payar $100 \mathrm{mV} / \mathrm{s}$ sebanyak 5 kali siklik dan diperoleh SPCE yang siap dimodifikasi. Larutan natrium poliakrilat $0.05 \%$ disiapkan dalam pelarut metanol. Sementara itu, larutan grafena dibuat dengan melarutkan sebanyak $1 \mathrm{mg}$ grafena dalam 1 $\mathrm{mL}$ kloroform. Larutan natrium poliakrilat dan grafena dicampurkan dengan perbandingan 1:1, kemudian campuran disonikasi selama 90 menit untuk proses homogenisasi. Sebanyak 8 $\mu \mathrm{L}$ campuran tersebut diteteskan ke permukaan elektrode kerja SPCE. SPCE termodifikasi grafena (SPCEG) didiamkan dalam suhu kamar. Sebelum digunakan dalam pengukuran, SPCEG dipayar secara voltametri siklik menggunakan elektrolit etanol 70\%:PB $0.1 \mathrm{M}$ pH 7 (6:4) pada jendela potensial -0.2 s.d. 0.8 $\mathrm{V}$ dengan kecepatan payar $100 \mathrm{mV} / \mathrm{s}$ sebanyak 7 kali siklik.

\section{Pencirian SPCE Termodifikasi Grafena}

Morfologi permukaan SPCE tanpa modifikasi, SPCE termodifikasi grafena dan natrium poliakrilat, serta SPCE termodifikasi natrium poliakrilat dianalisis menggunakan SEM (ZEISS EVOMA 10). Elektrode disalut dengan emas $(\mathrm{Au})$ menggunakan alat Sputter Coater (Quorum Q150R ES), kemudian dipasang pada tempat spesimen. Kondisi SEM diatur pada potensial pemercepat $16 \mathrm{kV}$, detektor secondary electron (SE), dan jarak kerja $6.5 \mathrm{~mm}$. Elektrode diamati pada perbesaran 500 dan 10000 kali.

\section{Optimasi pH Elektrolit}

Larutan bufer fosfat (PB) $0.1 \mathrm{M}$ dengan $\mathrm{pH} 4,5,6,7$, dan 8 dibuat dari $\mathrm{KH}_{2} \mathrm{PO}_{4}$ dan $\mathrm{K}_{2} \mathrm{HPO}_{4}$. Larutan elektrolit disiapkan dari campuran etanol $70 \%$ dan larutan bufer fosfat (PB) $0.1 \mathrm{M}$ dengan perbandingan 6:4 pada setiap variasi $\mathrm{pH}$ PB. Selanjutnya, SPCEG dalam larutan elektrolit dipayar pada jendela potensial -0.2 s.d. $0.8 \mathrm{~V}$ dengan kecepatan payar $100 \mathrm{mV} / \mathrm{s}$ sebanyak 7 kali siklik. $\mathrm{pH}$ optimum ditentukan berdasarkan respon arus paling tinggi pada voltamogram siklik yang dihasilkan saat pengukuran.

\section{Pengaruh Kecepatan Payar}

Elektrode SPCE tanpa modifikasi dan

SPCE termodifikasi grafena (SPCEG) digunakan untuk mengukur $\mathrm{K}_{3} \mathrm{Fe}(\mathrm{CN})_{6} 5 \times 10^{-3}$ $\mathrm{M}$ dalam $\mathrm{KCl} 5 \times 10^{-2} \mathrm{M}$ dengan variasi kecepatan payar, yaitu 50, 100, 150, 200, 250 $\mathrm{mV} / \mathrm{s}$. Pengukuran dilakukan secara voltametri siklik pada jendela potensial $-0,5$ s.d. 1,0 V. Hasil pengukuran dibuat hubungan antara respon arus oksidasi dan reduksi dari $\mathrm{K}_{3} \mathrm{Fe}(\mathrm{CN})_{6}$ (sumbu y) dengan akar kecepatan payar (sumbu $\mathrm{x}$ ).

\section{Deteksi Simultan Kuersetin dan Rutin}

Campuran kuersetin dan rutin diukur secara simultan menggunakan SPCE dan SPCEG yang mengacu pada Xiao et al., (2007) dengan modifikasi. Campuran kuersetin \& rutin $1 \mathrm{mM}$ dalam etanol 70\%:PB $0.1 \mathrm{M} \mathrm{pH} 7$ (6:4) disiapkan sebanyak $5 \mathrm{~mL}$. Larutan diukur menggunakan potensiostat pada jendela potensial -0.2 s.d. $0.8 \mathrm{~V}$ dan kecepatan payar $100 \mathrm{mV} / \mathrm{s}$ dengan teknik voltametri siklik. Permukaan elektrode dicuci dengan metanol p.a. atau etanol p.a. sebelum digunakan untuk pengulangan pengukuran selanjutnya.

\section{Kinerja Analitik SPCE dan SPCEG}

Evaluasi kinerja SPCE dan SPCEG untuk deteksi simultan kuersetin dan rutin dilakukan mengacu pada ICH (2005) dengan modifikasi. Larutan campuran kuersetin dan rutin $1,2,3,4$, dan $5 \mathrm{mM}$ dalam etanol 70\%:PB $0.1 \mathrm{M} \mathrm{pH} 7$ (6:4) disiapkan. Masingmasing larutan dipayar pada kondisi optimum pengukuran sebanyak 7 kali ulangan. Prosedur ini digunakan untuk menentukan linearitas, presisi, limit deteksi (LD), limit kuantitasi (LK), dan stabilitas.

\section{HASIL DAN PEMBAHASAN SPCE Termodifikasi Grafena}

Screen printed carbon electrode (SPCE) yang digunakan memiliki elektrode 
kerja berupa karbon, elektrode pembanding $\mathrm{Ag} / \mathrm{AgCl}$, dan elektrode penunjang berupa karbon. Karbon digunakan sebagai elektrode kerja karena memiliki arus latar belakang yang rendah, jendela potensial yang luas (kendati tidak sebaik boron doped diamond), lembam, dan murah. Kinerja elektrode kerja karbon dapat ditingkatkan melalui modifikasi secara kimia. Modifikasi tersebut bertujuan meningkatkan laju transfer elektron ke permukaan elektrode (Harvey, 2000; Wang, 2001). Pada penelitian ini, elektrode kerja SPCE dimodifikasi dengan grafena membentuk SPCEG untuk meningkatkan kinerja elektrokimianya. Teknik modifikasi yang digunakan adalah drop casting dengan cara meneteskan grafena di atas permukaan elektrode kerja SPCE.

A

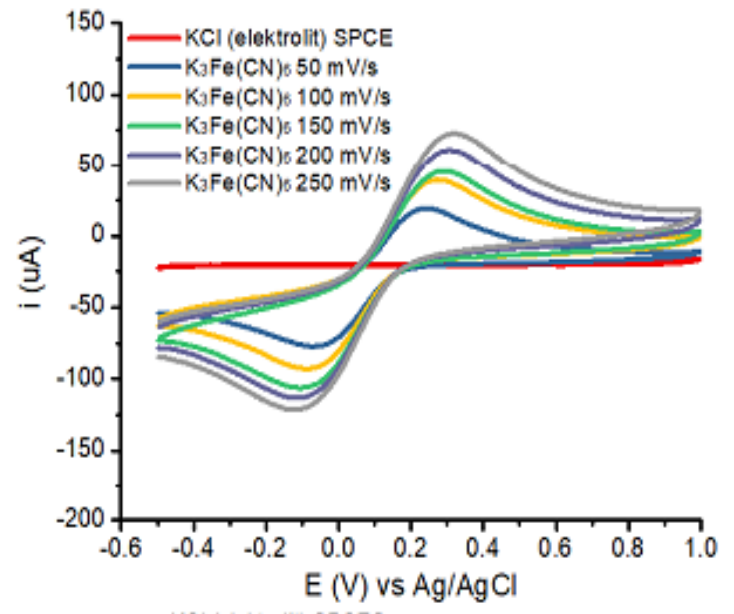

C

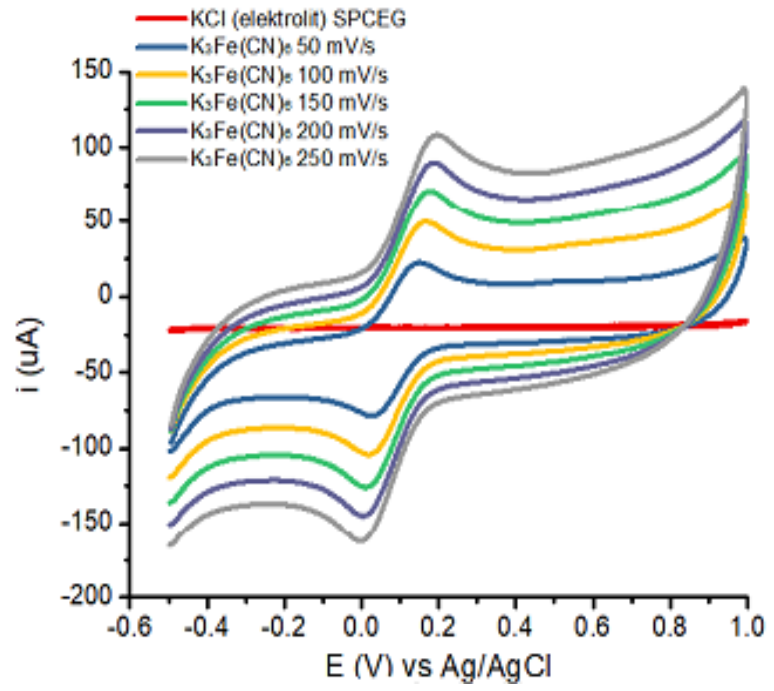

Grafena dapat meningkatkan aktivitas transfer elektron pada permukaan elektrode. Grafena memiliki susunan atom berkerangka heksagonal dan membentuk satu lembaran yang sangat teratur. Menurut Terrones et al., (2010), setiap atom karbon pada lapisan grafena memiliki orbital $\pi$ yang dapat bergerak bebas sehingga berpengaruh terhadap proses transfer elektron. Oleh karena itu grafena memiliki laju transfer elektron lebih tinggi dibandingkan grafit. Sementara itu, larutan natrium poliakrilat berfungsi sebagai perekat grafena pada permukaan elektrode kerja. Natrium poliakrilat merupakan polimer konduktif yang dapat memfasilitasi dispersi grafena sehingga grafena dapat tertahan pada permukaan elektrode kerja.

B

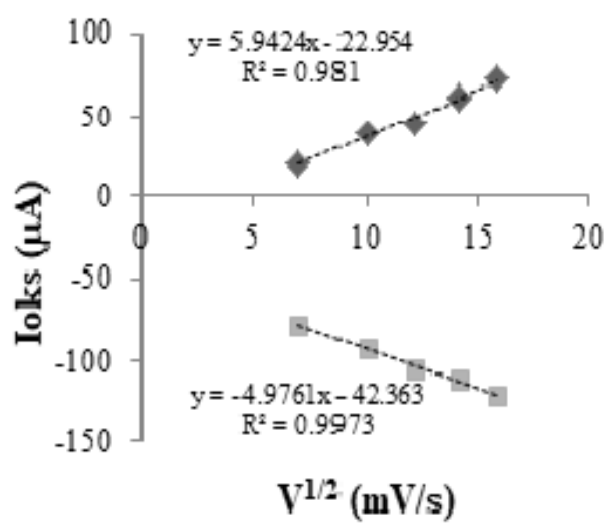

D

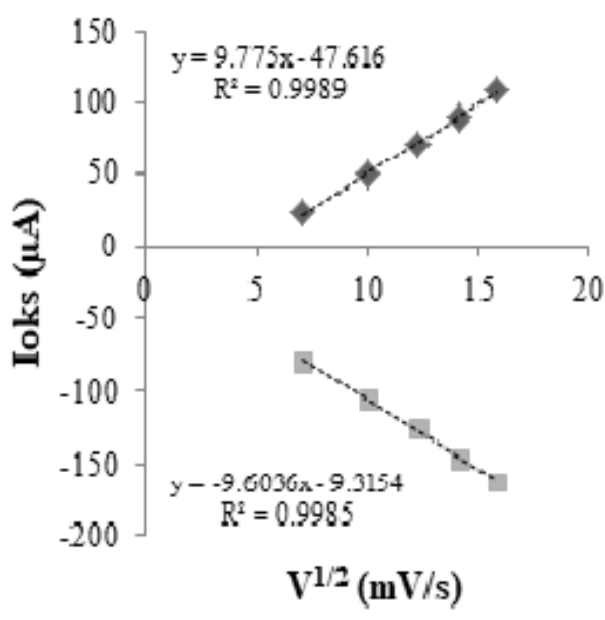

Gambar 1. Voltamogram siklik $\mathrm{K}_{3} \mathrm{Fe}(\mathrm{CN})_{6} 5 \mathrm{mM}$ dalam $0,05 \mathrm{MKCl}$ diukur dengan kecepatan payar 50 s.d. 250 $\mathrm{mV} / \mathrm{s}$ pada SPCE (A) dan SPCEG (C) dan kurva hubungan akar kecepatan payar dengan arus puncak oksidasi dan reduksi pada SPCE (B) dan SPCEG (D). 


\section{Performa transfer elektron pada} SPCEG dibandingkan dengan SPCE menggunakan spesi elektroaktif $\mathrm{K}_{3} \mathrm{Fe}(\mathrm{CN})_{6}$. Voltamogram yang diperoleh menunjukkan arus oksidasi dan reduksi spesi $\mathrm{K}_{3} \mathrm{Fe}(\mathrm{CN})_{6}$ pada SPCEG lebih tinggi dibandingkan SPCE, mengindikasikan proses transfer elektron pada SPCEG lebih baik dibandingkan SPCE (Gambar 1A dan 1C). Hasil pengukuran menunjukkan bahwa semakin tinggi kecepatan payar, maka semakin tinggi arus puncak oksidasi yang dihasilkan. Kecepatan payar yang tinggi mengakibatkan terbentuknya lapisan difusi yang tipis, sehingga transfer elektron di sekitar permukaan elektrode berlangsung dengan baik. Sebaliknya, kecepatan payar yang rendah akan mempertebal lapisan difusi, sehingga menghambat transfer elektron (Bard dan Faulkner, 2001). Namun demikian, penggunaan kecepatan payar tinggi tidak disarankan untuk mengamati spesi elektroaktif dengan kinetika reaksi yang lambat.

Voltamogram siklik larutan $\mathrm{K}_{3} \mathrm{Fe}(\mathrm{CN})_{6}$ menghasilkan arus puncak oksidasi berbanding lurus dengan akar kuadrat kecepatan payar $V^{1 / 2}$ (Gambar 1B dan 1D). Berdasarkan persamaan Randless-Sevcik, arus puncak oksidasi dan reduksi $(I)$ yang berbanding lurus dengan akar kuadrat kecepatan payar $\left(V^{I / 2}\right)$ menunjukkan bahwa transfer muatan dari larutan ke permukaan elektrode berlangsung secara difusi, disebabkan oleh perubahan gradien konsentrasi (Scholz, 2010). Gradien konsentrasi yang semakin tinggi menyebabkan reaksi redoks berjalan cepat sehingga intensitas arus meningkat.

\section{Morfologi Permukaan SPCE Termodifikasi Grafena}

Analisis SEM dilakukan untuk mengamati keberadaan grafena dan natrium poliakrilat di permukaan SPCE termodifikasi grafena (Gambar 2). Berdasarkan hasil SEM, SPCE memiliki permukaan yang tidak rata (Gambar 2A). Sementara permukaan SPCEG terlihat tertutupi oleh molekul dan membentuk aglomerasi (Gambar 2B). Menurut Stoller et al., (2008), morfologi permukaan grafena menunjukkan adanya aglomerasi dengan ukuran partikel $15-25 \mu \mathrm{m}$ saat diamati menggunakan SEM.
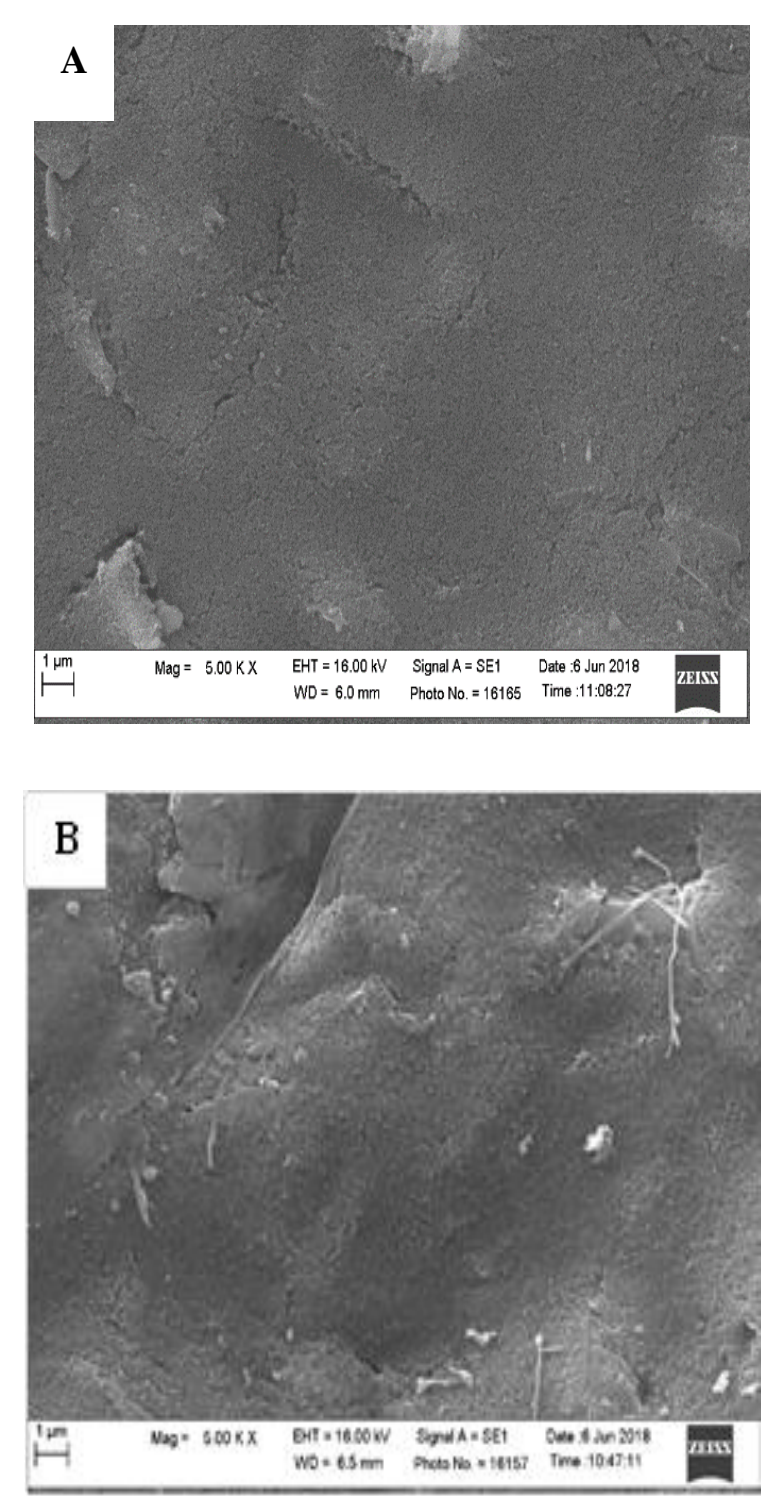

Gambar 2. Morfologi permukaan SPCE (A), SPCEG (B) diamati menggunakan SEM pada perbesaran 5000 kali.

\section{Elektrolit Pengukuran Kuersetin dan Rutin}

Larutan elektrolit berfungsi mempertahankan kekuatan ion. Penelitian ini menggunakan elektrolit berupa campuran bufer fosfat (PB) $0.1 \mathrm{M}$ dengan etanol 70\%. Etanol berfungsi untuk melarutkan kuersetin. Menurut Abraham dan Acree, (2014), kelarutan kuersetin meningkat seiring dengan meningkatnya konsentrasi etanol lalu konstan setelah konsentrasi etanol mencapai $70 \%$. Oleh karena itu, penelitian ini menggunakan etanol $70 \%$ yang ditambahkan pada PB $0.1 \mathrm{M}$.

Pengaruh $\mathrm{pH}$ elektrolit diamati dengan membandingkan voltamogram siklik kuersetin dan rutin dalam elektrolit dengan variasi $\mathrm{pH}$ 
larutan PB. Berdasarkan voltamogram siklik yang diperoleh (Gambar 3) teramati bahwa pada kisaran $\mathrm{pH} 4$ hingga $\mathrm{pH} 7$, kenaikan nilai $\mathrm{pH} \mathrm{PB}$ akan meningkatkan intensitas arus oksidasi analit. Namun demikian, saat $\mathrm{pH} 8$ terjadi penurunan intensitas arus oksidasi. Hal ini dapat dijelaskan karena pada kondisi asam keberadaan ion $\mathrm{H}^{+}$yang tinggi dapat menghambat oksidasi kuersetin dan rutin, menyebabkan reaksi bergeser ke kiri dan menurunkan jumlah elektron yang terbentuk sehingga terjadi penurunan arus oskidasi (Tehrani et al., 2013). Kenaikan nilai pH hingga $\mathrm{pH} 7$ menyebabkan jumlah ion $\mathrm{H}^{+}$ semakin berkurang, sehingga mendorong reaksi oksidasi kuersetin dan rutin (Gambar 4). Penurunan arus pada $\mathrm{pH} 8$ terjadi akibat proses deprotonasi (Xiao et al., 2007). Intensitas optimum arus oksidasi dihasilkan saat pengukuran elektrolit dengan kondisi $\mathrm{PB}$ pH 7 sehingga elektrolit yang digunakan pada pengukuran kuersetin dan rutin ialah etanol 70\%:PB 0.1 M pH 7 dengan perbandingan 6:4.

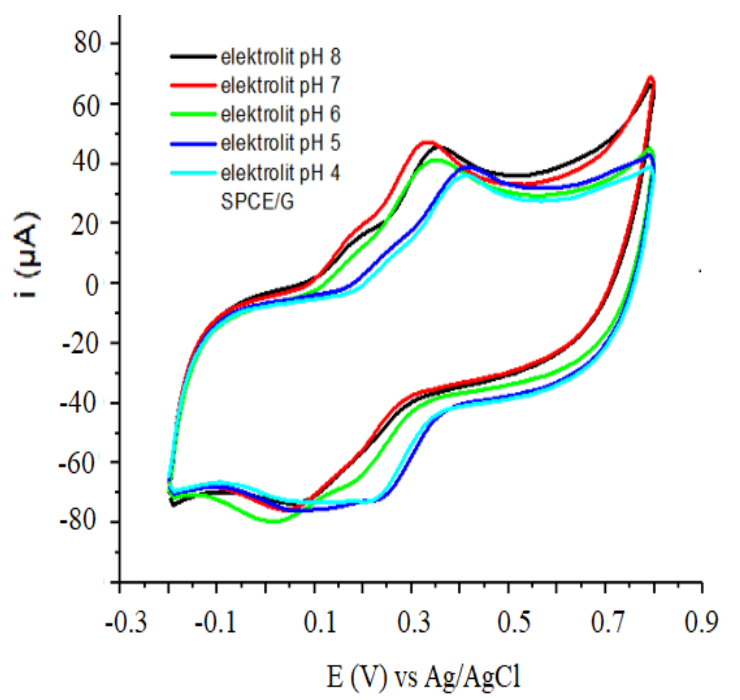

Gambar 3. Voltamogram siklik campuran kuersetin dan rutin dalam elektrolit etanol 70\%:PB $0.1 \mathrm{M}$ pH 4 hingga $\mathrm{pH} 8$.

\section{Reaksi Oksidasi Kuersetin dan Rutin Melalui Voltametri Siklik}

Voltamogram siklik kuersetin dan rutin disajikan pada Gambar 5. Voltamogram siklik kuersetin menunjukkan satu puncak oksidasi pada potensial $0.18 \mathrm{~V}$ vs $\mathrm{Ag} / \mathrm{AgCl}$ dan satu puncak reduksi pada potensial $0.07 \mathrm{~V}$ vs $\mathrm{Ag} / \mathrm{AgCl}$ (Gambar 5A). Adanya puncak oksidasi diduga berasal dari oksidasi gugus -
$\mathrm{OH}$ pada cincin B. Puncak reduksi muncul akibat reaksi reversibel gugus hidroksil pada cincin B yang melibatkan 2 elektron. Breet dan Ghica (2003) melaporkan voltamogram siklik kuersetin dalam elektrolit PB $0.2 \mathrm{M}$ pH 7.7 pada elektrode karbon gelas menghasilkan 4 puncak oksidasi dan 1 puncak reduksi. Puncak oksidasi berasal dari oksidasi 3 gugus $-\mathrm{OH}$ pada cincin $\mathrm{A}$ dan $\mathrm{C}$, serta gugus $-\mathrm{OH}$ pada cincin B. Oksidasi gugus $-\mathrm{OH}$ pada cincin $\mathrm{B}$ terjadi pada potensial paling rendah, yaitu puncak oksidasi pertama $(0.15 \mathrm{~V}$ vs $\mathrm{Ag} / \mathrm{AgCl})$ dan memiliki intensitas paling tinggi. Puncak reduksi muncul pada potensial $0.10 \mathrm{~V}$ vs $\mathrm{Ag} / \mathrm{AgCl}$ (Gambar 5B). Oksidasi selanjutnya terjadi pada gugus hidroksil cincin $\mathrm{C}$ (puncak kedua $0.30 \mathrm{~V}$ vs $\mathrm{Ag} / \mathrm{AgCl}$ ). Puncak oksidasi ketiga dan keempat muncul pada potensial lebih positif, yaitu $0.60 \mathrm{~V}$ dan $0.80 \mathrm{~V}$ vs $\mathrm{Ag} / \mathrm{AgCl}$, berasal dari gugus hidroksil pada cincin A (Breet dan Ghica, 2003). Perbedaan jumlah puncak redoks kuersetin yang diperoleh pada penelitian ini dan yang dilaporkan Breet dan Ghica, (2003) dapat terjadi karena kondisi pengukuran yang berbeda, seperti perbedaan elektrode kerja yang digunakan, larutan elektrolit, kondisi $\mathrm{pH}$, dan kecepatan pemayaran. Etanol yang digunakan dalam penelitian ini berfungsi melarutkan kuersetin dan berperan sebagai katalis dalam reaksi kuersetin menjadi ortokuinon, sehingga hanya mengalami satu kali oksidasi (Zielinska et al., 2008).

Voltammogram siklik rutin pada SPCEG menunjukkan satu puncak oksidasi dan satu puncak reduksi masing-masing pada $0.19 \mathrm{~V}$ dan $0.03 \mathrm{~V}$ vs $\mathrm{Ag} / \mathrm{AgCl}$ (Gambar 5C). Puncak oksidasi rutin diduga berasal dari aktivitas dua gugus $-\mathrm{OH}$ pada cincin $\mathrm{B}$. Reaksi melibatkan 2 elektron dan 2 proton yang berlangsung secara reversibel. Menurut Ghica dan Brett, (2004) voltamogram siklik rutin dalam bufer asetat $0.2 \mathrm{M} \mathrm{pH} 4.5$ yang diukur dengan elektrode kerja gelas karbon menghasilkan dua puncak oksidasi dan satu puncak reduksi (Gambar 5D). Oksidasi pertama terjadi pada 2 gugus $-\mathrm{OH}$ cincin $\mathrm{B}$ yang muncul pada potensial $0.460 \mathrm{~V}$ vs $\mathrm{Ag} / \mathrm{AgCl}$. Puncak reduksi berada pada potensial $0.432 \mathrm{~V}$ vs $\mathrm{Ag} / \mathrm{AgCl}$. Terbentuknya puncak oksidasi kedua akibat dari aktivitas gugus $-\mathrm{OH}$ pada cincin $\mathrm{A}$. Puncak kedua muncul pada potensial $1.08 \mathrm{~V}$ vs $\mathrm{Ag} / \mathrm{AgCl}$, tetapi memiliki intensitas arus yang lebih rendah dibandingkan puncak oksidasi pertama. 
A<smiles>CCc1ccc(-c2oc3cc(O)cc(O)c3c(=O)c2O)cc1O</smiles>

B<smiles></smiles>

$\mathbf{C}$

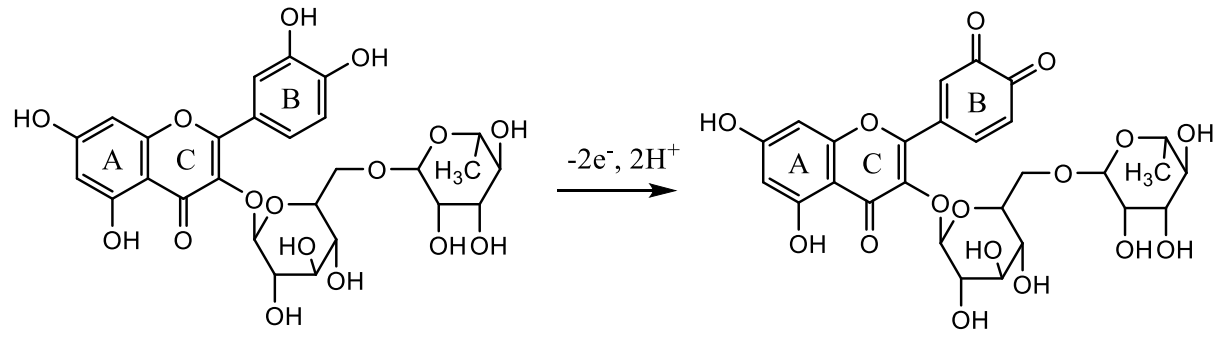

Gambar 4. Reaksi oksidasi kuersetin (Tehrani et al., 2013) (A) reaksi kesetimbangan kuersetin menurut Yola et al., (2013) (B), reaksi redoks rutin menurut Franzoi et al. (2008)
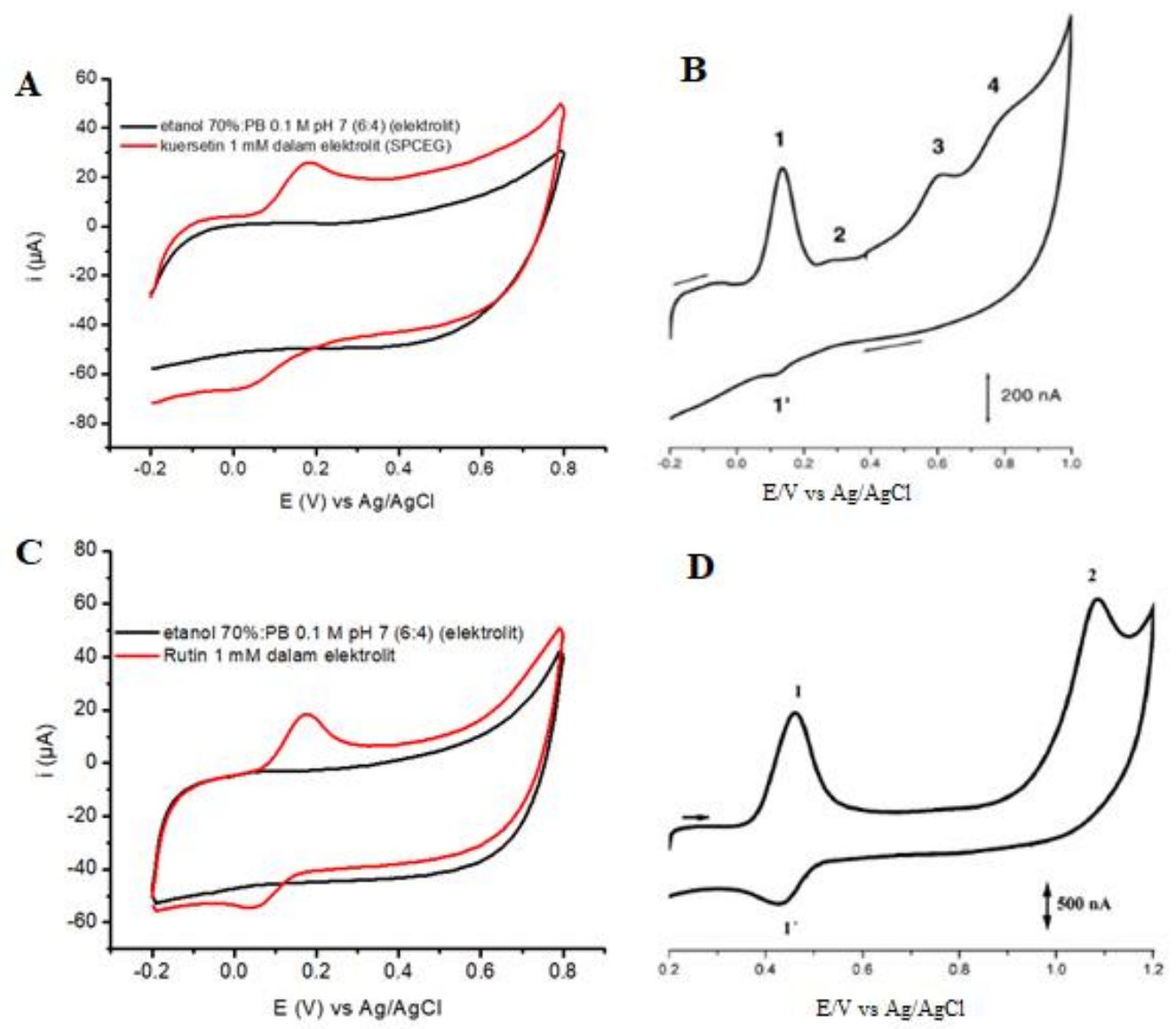

Gambar 5. Voltamogram siklik kuersetin $1 \mathrm{mM}$ dalam etanol 70\%:PB $0,1 \mathrm{M} \mathrm{pH} 7$ (6:4) kecepatan payar 100 $\mathrm{mV} / \mathrm{s}$ pada SPCEG (A), dalam elektrolit PB $0.2 \mathrm{M} \mathrm{pH} \mathrm{7,7} \mathrm{kecepatan} \mathrm{payar} 50 \mathrm{mV} / \mathrm{s}$ pada elektrode karbon gelas (B) (Brett dan Ghica, 2003), dalam elektrolit etanol 70\%:PB $0.1 \mathrm{M} \mathrm{pH} 7$ (6:4) kecepatan payar $100 \mathrm{mV} / \mathrm{s}$ pada SPCEG (C), dan dalam elektrolit bufer asetat $0,2 \mathrm{M} \mathrm{pH} 4.5$ kecepatan payar $100 \mathrm{mV} / \mathrm{s}$ pada elektrode karbon gelas (D) (Ghica dan Brett, 2004). 


\section{Respon Elektrokimia Kuersetin dan Rutin Menggunakan SPCE Termodifikasi Grafena Secara Voltametri Siklik}

Deteksi simultan kuersetin dan rutin dilakukan menggunakan SPCE dan SPCEG. Berdasarkan voltamogram siklik yang diperoleh, pengukuran campuran kuersetin dan rutin pada SPCE menghasilkan 2 puncak oksidasi (Gambar 6A). Puncak pertama merupakan puncak oksidasi kuersetin, muncul pada potensial $0.129 \mathrm{~V}$ vs $\mathrm{Ag} / \mathrm{AgCl}$. Puncak kedua merupakan puncak oksidasi rutin yang muncul pada potensial $0.263 \mathrm{~V}$ vs $\mathrm{Ag} / \mathrm{AgCl}$. Pengukuran pada SPCEG menunjukkan respon arus puncak oksidasi analit yang lebih tinggi dibandingkan SPCE (Gambar 6A). Kenaikan intensitas arus oksidasi kuersetin dan rutin pada SPCEG diduga akibat keberadaan grafena yang memiliki struktur ikatan $\mathrm{sp}^{2}$ pada atom karbonnya. Elektron pada orbital $\pi$ dapat bergerak bebas sehingga transfer elektron dapat terjadi lebih cepat. Dengan demikian, SPCEG dapat meningkatkan sensitivitas pengukuran pada deteksi kuersetin dan rutin. Pengukuran menggunakan SPCEG juga menghasilkan 2 puncak oksidasi, puncak pertama merupakan arus puncak oksidasi kuersetin pada potensial $0.179 \mathrm{~V}$ vs $\mathrm{Ag} / \mathrm{AgCl}$ dan puncak kedua merupakan puncak oksidasi rutin pada potensial $0.310 \mathrm{~V}$ vs $\mathrm{Ag} / \mathrm{AgCl}$.

Pengukuran simultan kuersetin dan rutin selanjutnya dilakukan pada konsentrasi analit yang bervariasi. Analit berupa campuran kuersetin dan rutin dengan konsentrasi 1 s.d. 5 $\mathrm{mM}$ yang diukur menggunakan SPCE dan SPCEG. Peningkatan konsentrasi analit menghasilkan arus puncak oksidasi yang semakin tinggi (Gambar 6B dan Gambar 6C). Ketika pengukuran menggunakan SPCEG, respon arus puncak oksidasi lebih tinggi dibandingkan dengan SPCE. Voltamogram siklik analit pada konsentrasi yang bervariasi menunjukkan adanya pergeseran potensial oksidasi ke arah lebih positif pada SPCEG (Gambar 6C).

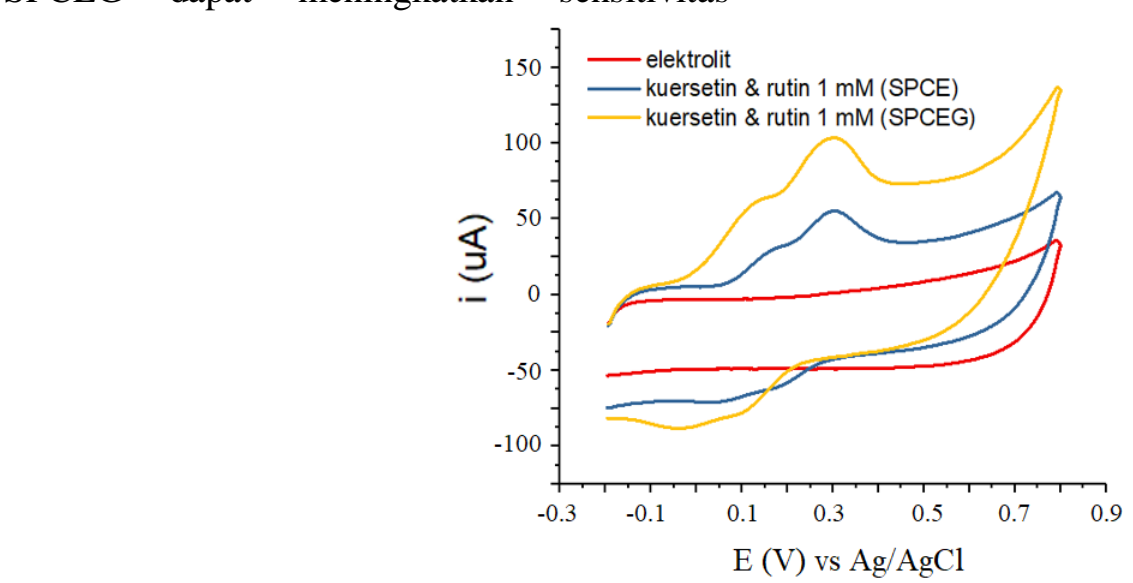

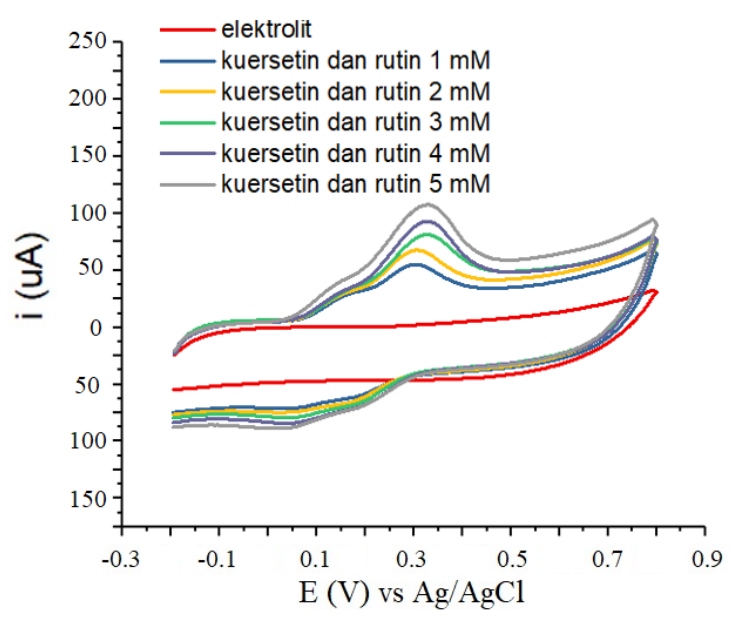

B

A

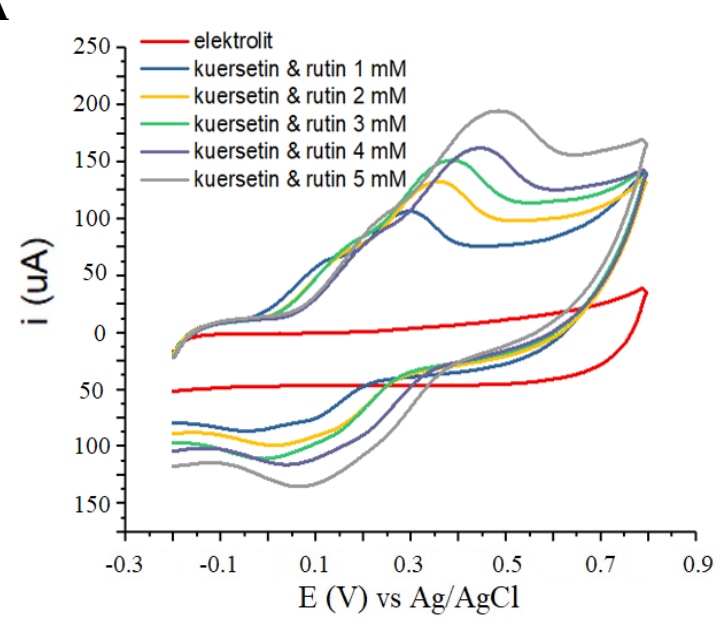

C

Gambar 6. Voltamogram siklik campuran kuersetin dan rutin $1 \mathrm{mM}$ pada SPCE dan SPCEG, kecepatan payar $100 \mathrm{mV} / \mathrm{s}$ (A) dan voltamogram siklik campuran kuersetin dan rutin konsentrasi 1-5 mM pada SPCE (B) dan SPCEG $(\mathrm{C})$. 


\section{Kinerja Analitik SPCE dan SPCEG untuk Deteksi Simultan Kuersetin dan Rutin Linearitas}

Evaluasi linearitas dilakukan dengan melihat nilai koefisien determinasi $\left(R^{2}\right)$ dari persamaan regresi linear. Pengukuran menggunakan SPCE menghasilkan persamaan regresi linear $\mathrm{y}=1.9802 \mathrm{x}+24.739\left(R^{2}=\right.$ $0.9442)$ untuk deteksi kuersetin dan y $=$ $8.5715 \mathrm{x}+48.767\left(R^{2}=0.9388\right)$ untuk deteksi rutin. Sementara itu, pengukuran menggunakan SPCEG mendapatkan persamaan regresi linear $\mathrm{y}=7.3925 \mathrm{x}+51.887\left(R^{2}=0.9905\right)$ untuk deteksi kuersetin dan y $=23.556 \mathrm{x}+77.316\left(R^{2}\right.$ $=0.9816)$ untuk deteksi rutin. Berdasarkan hasil tersebut, nilai koefisien determinasi $\left(R^{2}\right)$ SPCEG lebih baik dibandingkan SPCE (Tabel $1)$.

\section{Presisi}

Presisi dinyatakan dalam nilai \%SBR, semakin kecil nilainya maka teknik yang digunakan semakin teliti. Nilai \%SBR untuk SPCE pada pengukuran simultan sebesar 3.54 pada deteksi kuersetin dan $4.74 \%$ pada deteksi rutin. Sementara itu, nilai \%SBR untuk SPCEG, yaitu $2.14 \%$ pada deteksi kuersetin dan $2.44 \%$ pada deteksi rutin (Tabel 1). Nilai $\%$ SBR pada SPCE dan SPCEG bernilai kurang dari 5\%, dapat dikatakan teknik voltametri siklik pada deteksi simultan kuersetin dan rutin cukup teliti (ICH, 2005).

\section{Limit Deteksi (LD) dan Limit Kuantitasi (LK)}

Nilai LD deteksi kuersetin dan rutin pada SPCEG, yaitu $0.5369 \mathrm{mM}$ dan 0.7495 $\mathrm{mM}$, sedangkan pada SPCE LD sebesar 1.3317 $\mathrm{mM}$ dan $1.3984 \mathrm{mM}$. Nilai LD tersebut menunjukkan SPCEG lebih sensitif dibandingkan SPCE untuk deteksi simultan kuersetin dan rutin. Nilai LK pengukuran kuersetin pada SPCEG 2.48 kali lebih rendah dibandingkan pada SPCE, sementara pada pengukuran rutin LK pada SPCEG 1.87 kali lebih rendah dibandingkan pada SPCE (Tabel 1). Hal ini menunjukkan grafena pada SPCE dapat meningkatkan sensitivitas pengukuran dan dapat digunakan untuk pengukuran pada konsentrasi rendah.

Tabel 1. Ringkasan kinerja analitik SPCE dan SPCEG untuk deteksi simultan kuersetin dan rutin

\begin{tabular}{lllll}
\hline \multirow{2}{*}{\multicolumn{1}{c}{ Parameter }} & \multicolumn{2}{c}{ Kuersetin } & \multicolumn{2}{c}{ Rutin } \\
\cline { 2 - 5 } & SPCE & SPCEG & SPCE & SPCEG \\
\hline Pengukuran potensial puncak $(\mathrm{V})$ & 0.129 & 0.179 & 0.263 & 0.310 \\
Selang Linearitas $(\mathrm{mM})$ & $1-5$ & $1-5$ & $1-5$ & $1-5$ \\
Kemiringan $(\mu \mathrm{A} / \mathrm{mM})$ & 1.980 & 7.3925 & 8.5715 & 23.556 \\
Intersep $(\mu \mathrm{A})$ & 24.739 & 51.887 & 48.767 & 77.316 \\
Koefisien Determinasi $\left(R^{2}\right)$ & 0.9442 & 0.9905 & 0.9388 & 0.9816 \\
LD $(\mathrm{mM})$ & 1.3317 & 0.5369 & 1.3984 & 0.7495 \\
LK $(\mathrm{mM})$ & 4.4389 & 1.7898 & 4.6614 & 2.4985 \\
Presisi Pengukuran $(\% \mathrm{SBR})$ & 3.54 & 2.14 & 4.74 & 2.44 \\
\hline
\end{tabular}

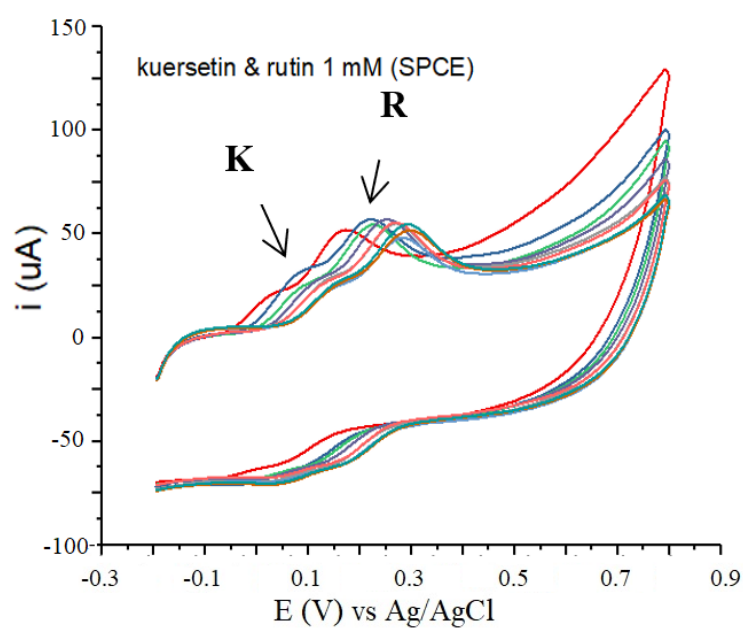

A

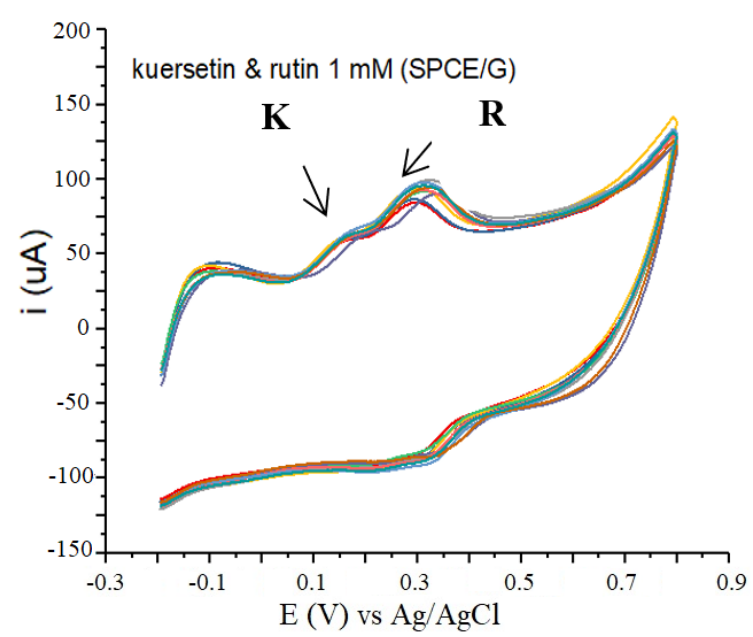

B

Gambar 7. Voltamogram siklik uji stabilitas SPCE dengan 8 kali siklik (A) dan SPCEG dengan 10 kali siklik (B) (Ket: $\mathrm{K}=$ kuersetin, $\mathrm{R}=$ rutin) 


\section{Stabilitas}

Evaluasi stabilitas dilakukan dengan melakukan pengukuran secara berulang kali pada kondisi yang sama hingga didapatkan \%SBR. Pengukuran campuran kuersetin dan rutin menggunakan SPCE stabil hingga pemayaran ke-8, setelah pemayaran ke-8 nilai $\%$ SBR $>5 \%$. Sementara itu, pada pengukuran menggunakan SPCEG respon arus oksidasi stabil hingga pemayaran ke-10. Setelah pemayaran ke-10 nilai \%SBR > 5\%. Hasil yang diperoleh menunjukkan semakin banyak pemayaran intensitas arus semakin turun (Gambar 7). Hal ini diduga disebabkan permukaan elektrode tertutupi oleh produk oksidasi yang tidak lepas sepenuhnya dari permukaan elektrode. Hasil pengamatan yang dilakukan (data tidak ditunjukkan) menjelaskan bahwa pembilasan elektrode dapat mengusir produk oksidasi dan sehingga presisi pengukuran lebih tinggi.

\section{SIMPULAN}

Modifikasi screen printed carbon electrode (SPCE) dengan grafena telah berhasil dilakukan menggunakan teknik drop casting. SPCE termodifikasi grafena (SPCEG) yang dihasilkan memiliki kemampuan transfer elektron lebih tinggi pada pengukuran dengan teknik voltametri. SPCEG tersebut telah digunakan untuk deteksi kuersetin dan rutin secara simultan dengan teknik voltametri siklik. Kinerja analitik SPCEG dalam mendeteksi kuersetin dan rutin menunjukkan nilai linearitas, presisi, limit deteksi, limit kuantitasi, dan stabilitas yang lebih baik dibandingkan SPCE.

\section{DAFTAR PUSTAKA}

Abraham MH, Acree WE. 2014. On the solubility of quercetin. J. Mol. Liq. doi:10.1016/j.molliq.2014.05.006.

Bard AJ, Faulkner LR. 2001. Electrochemical Methods: Fundamental and Applications. Second edition. New York: Wiley. ISBN: 0-471-04372-9

Brett AMO, Ghica ME. 2003. Electrochemical oxidation of quercetin. Electroanalysis. 15(22): $\quad 1745-1750 . \quad$ doi: 10.1002/elan.200302800.
Franzoi AC, Spinelli A, Vierira IC. 2008. Rutin determination in pharmaceutical formulations using a carbon paste electrode modified with poly(vinylpyrrolidone). J. Pharm. Biomed. Anal. 47: 973-977. doi: 10.1016/j.jpba.2008.03.0.

Ganeshpurkar A, Saluja AK. 2016. The pharmacological potential of rutin. $J$. Saudia Pharm. 25: 149-164.

Ghica ME, Brett AMO. 2004. Electrochemical oxidation of rutin. Electroanalysis. 17(4): 313-318. doi: 10.1002/elan.200403100.

[ICH] International Conference on Harmonisation. 2005. Validation of Analytical Procedures.

Harvey D. 2000. Modern Analytical Chemistry. New York (US): McGraw-Hill.

Jampasa S, Siangproh W, Duangmal K, Chailapakul O. 2016. Electrochemically reduced graphene oxide-modified screenprinted carbon electrodes for a simple and highly sensitive electrochemical detection of synthetic colorants in beverage. Talanta. 16: 1-31. doi: 10.1016/j.talanta.2016.07.011.

Kelly KF, Billups WE. 2012. Synthesis of soluble graphite and graphene. Acc. Chem. Res. 46(1): 4-13. doi: 10.1021/ar300121q.

Lin XQ, He JB, Zha ZG. 2006. Simultaneous determination of quercetin and rutin at a multi-wall carbon-nanotube paste electrodes by reversing differential pulse voltammetry. Sens. Actuators. 119: 608614. doi: 10.1016/j.snb.2006.01.016.

Ozgen S, Kilinc OZ, Selamoglu Z. 2016. Antioxidant activity of quercetin: a mechanistic review. Food Sci. Techno. 4(12): 1134-1138. doi: 10.24925/turjaf.v4i12.1134-1138.1069.

Piovesan JV, Spinelli A. 2014. Determination of quercetin in a pharmaceutical sample by square-wave voltammetry using a poly(vinylpyrrolidone)-modified carbonpaste electrode. J. Braz. Chem. 25(3): 517-525. doi: 10.5935/01035053.20140019.

Scholz F, editor. 2010. Electroanalytical Methods Guide to Experiments and Applications. Ed ke-2. Heidelberg (DE): Springer. doi: 10.1016/0021-9673(95)01281-8. 
Stoller MD, Park S, Zhu Y, An J, Ruoff RS. 2008. Graphene-based ultracapacitors. Nano. Lett. 8(10): 3498-3502. doi: $10.1021 / \mathrm{nl} 802558 \mathrm{y}$.

Sun S, Zhang M, Li Y, He X. 2013. A molecularly imprinted polymer with incorporated grapheme oxide for electrochemical determination of quercetin. Sensors. 13: 5493-5506. doi: 10.3390/s130505493.

Sun W, Yang M, Li Y, Jiang Q, Liu S, Jiao K. 2008. Electrochemical behavior and determination of rutin on a pyridiniumbased ionic liquid modified carbon paste electrode. J. Pharm. Biomed. Anal. 48: 1326-1331.

doi: 10.1016/j.jpba.2008.09.014.

Tehrani MS, Pourhabib, Husain SW, Arvand M. 2013. Electrochemical behavior and voltammetric determination of quercetin in foods by grapheme nanosheets modified electrode. Anal. Biochem. Electrochem. 5(1): $1-18$.

Teng Y, Chen T, Xu F, Zhao W, Liu W. 2016. Screen-printed carbon electrode modified with commercial multilayer graphene for lead detection in soybean sauces by differential pulse stripping voltammetry. Int. J. Electrochem. Sci. 11: 1907-1917.

Terrones AR, Botello-Mendez AR, CamposDelgado J, Lopez-Urias F, Vega-Cantu YI, Rodriguez-Macias FJ, Elias AL, MunozSandoval E, Cano-Marquez AG, Charlier J, Terrones H. 2010. Graphene and graphite nanoribbons: morphology, properties, synthesis, defects and applications. Nano Today. 5(4): 351-372.
Wang J. 2001. Analytical Electrochemistry Second Edition. New York (US): John Wiley \& Sons, Inc.

Xiao P, Zhao F, Zeng B. 2007. Voltammetric determination of quercetin at multi-walled carbon nanotubes paste electrode. Microchem J. 85: 244-249.

Yola ML, Atar N, Unstundag Z, Solak AO. 2013. A novel voltammetric sensor based on $\mathrm{p}$ aminothiophenol functionalized graphene oxide/gold nanoparticles for determining quercetin in the presence of ascorbic acid. J. Electroanal. Chem. 698: 9-16. doi: 10.1016/j.jelechem.2013.03.016.

Yola ML, Atar N. 2014a. A novel voltammetric sensor based on gold nanoparticles involved in p-aminothiophenol functionalized multi-walled carbon nanotubes: application to the simultaneous determination of quercetin and rutin. Electrochim. Acta. 119: 24-31. doi: 10.1016/j.electacta.2013.12.028.

Yola ML, Gupta VK, Eren T, Sen AE, Atar N. 2014. A novel electro analytical nanosensor based on graphene oxide/silvernanoparticles for simultaneous determination of quercetin and morin. Electrochim. Acta. 120: 204-211. doi: 10.1016/j.electacta.2013.12.086.

Zielinska D, Nagels L, Piskula MK. 2008. Determination of quercetin and its glucosides in onion by electrochemical methods. Anal. Chem. Acta. 617: 22-31. 